\title{
Translation Problems of Phraseological Units: On the Basis of M. Auezov's Novel "the Way of Abai"
}

\section{Anvar Sauatovich Tarakov}

Doctor of Philological Sciences Email: Anuar_tarak@mail.ru

Indira Kairatovna Azimbayeva

PhD doctoral student Email: indira_azimbayeva@list.ru

\section{Zhibek Turarovna Abdullayeva}

Candidate of Philological Sciences, Al-Farabi Kazakh National University, Republic of Kazakhstan, 050038, Almaty, al-Farabi Ave., 71

zhibek.aknur@mail.ru

\section{Doi:10.5901/mjss.2015.v6n4s2p370}

\section{Abstract}

The important ways and methods of transferring phraseological units from source language into target one are considered in the following article. The national and cultural features put in the phraseological unit often becomes the difficult phenomenon throughout the translation of a figurative steady turn from original language into language-analog. The phraseological picture of the world occurring in consciousness of one language community does not always coincide with attitude of another community. To search an acceptable option of understanding in case of contact of different cultures the translator resorts to methods of the descriptive interpretation which systematization is a task of this article. The significance of a translator's personality during translation is also emphasized in the given article.

Keywords: Phraseological unit, translation language, phraseological translation, non-phraseological translation, interpretation, comparative studies, literary translation, reception, adequate reproduction, equivalent.

\section{Introduction}

In recent years, after analyzing the work of our scientists, we can note that interest and significance to rich and informative art of speech, which has been kept by our people for many centuries, has increased. In this connection there are plenty of problems in comparative literature and translation theory, which have been investigated and still are waiting for the research continuation. Consequently, translation questions of phraseological units into other languages, study the level of their presence in general artistic translation are the most significant tasks in Translation Studies Science.

From the 1940s phraseological units have been examined in diverse aspects of Kazakh Linguistics, such as structural-typological, semantic-morphological and thematic. For the first time founder of Kazakh phraseology I.Kenesbayev laid the theoretical foundation for the General Turkic Phraseology Science. Currently, theoretical and practical problems of phraseological units (A.Kaydar, A.Bolganbayev, G.Kaliyev, S.Isabekova, A.Aldasheva, G.Smagulova, S.Satenova and others), their stylistic functions (M.Sergaliyev, G.Kusimova, G.Boranbayeva), their use in work of fiction (O.Aytbayev, B.Shalabay, Kh.Kozhakhmetova, M.Zhanibekov), classification of phraseological units by meaningful, thematic aspects (A.Eleshova, R.Zhaysakova), particular categories of phraseological units (F.Orazbayeva, A.Baytaliyeva, R.Tayeva), phraseological units' dialectical features (Sh.Sarybayev, K.Kalybayeva, S.Mustafauly), comparative research of phraseological units with the data of peculiar languages (A.Amanzholov, Z.Akhmetzhanova, R.Valikhanova, M.Abdigaliyeva, P.Dauletova and others) and other matters have been studied in various prospects of Linguistics. Nevertheless, comprehensive exploring of Kazakh language phrasicon is one of the basic points at the present time» (Avakova, 2009). Translation of phraseological units into other languages is one of the less investigated directions in Translation Studies Science. Among the first O.Aytbayev studied the translation problems of phraseological 
units into Kazakh language in M.Gorky' work, in his research work "Phraseological phenomenon in translation" he analyzed theoretical opinions concerning to translation of general set expressions. The scholar divided translation of the phraseological units, proverbs and sayings into 3 ways: "Firstly, if we totally present subject meanings of the words in proverbs and sayings it is possible to translate them exactly. Secondly, to translate subject meanings of some words just a bit changing them. Thirdly, it is necessary to use phraseological units, proverbs and sayings of the translatable language" (Aytbayev, 1975). Critic M.Karatayev studied explicitly the principles of idiom translation relating to translation of the novel "Quietly flows the Don" and expressed his correct solution to the point. Translations of idioms into Kazakh language in the work of N.V.Gogol, different methods of delivering were examined in the book of Candidate of Philological Science S.Talzhanov "About fiction translation". This question was also studied from all sides in the thesis work of prominent researcher R.Sarsenbayev. Besides, the research work and scientific articles of K.Sagyndykov, A.Aldasheva, G.Aytzhanova are devoted to the given problem. As one of the most unique investigation among them we can name a study guide of A.Aldasheva published in 2006 "Translation Studies: linguistic and lingvocultural problems". In the book the language of prose work translated from Russian into Kazakh language is studied from the scholars' views, from the aspects of linguistic and lingvocultural sciences. An accurate scientific analysis was done about translation and Kazakh national culture, the role of translation in the lexical- grammatical system development of Kazakh literary language, national view in translation, singularity of word selection in translation and so on. Apart from this, in the section named "Phraseological units in translation versions", national-ethnic characteristics in the semantics of phraseological units, their functions, equivalent phraseological units and phraseological locution translated word for word are given. The scholar believes that it is significant to pay attention to the semantic structure of fixed phrase in the translation language and after studying other researchers' opinions the author came to a conclusion that: "Word for word, adequate and free translation methods are used to translate phraseological combination. Stylistic functions' transferrings of phraseological units translated word for word, adequate and free differ from each other. The most significant feature of phraseological locution in each language is close connection between set of patterns which can be basis for phraseological combination and material, social and moral culture of the people. In other words, it is quite possible to know cultural-national customs and traditions of the people through meaning and etymology of the basic component of phraseological units. Phraseological locution appeared from the people's worldview experience can have no adequate or close equivalent in the second language. For instance, fixed phrases used to denote symbolic function through the meaning, symbolic wordcombinations which have national distinctive indications (rainy day, black envy); phrases concerning to theologicalreligious concepts and notions (to fill up the cup, the salt of the earth); idioms (Cousin seven times removed, to twirl the goat horn, to tighten one's belt); phrases based on national-daily philosophy (women's brain, goldfish memory ); phraseological units centered around customs and traditions (to recruit smb) can have no exact and adequate equivalent meanings in Kazakh language as they are mainly related to the national-cultural entity of Russian people, it is quite common situation" (Aldasheva, 2006).

To translate phraseological units from one language into another is one of the most difficult tasks. It is not enough to transfer complete meaning of the idioms in the translation; a translator should try to convey national spirit of the fixed phrase. Kazakh, Kyrgyz, Turkish scholars have common opinions about the given point. We can prove our view by the conception of certain researchers. Kyrgyz academic N.K.Abdyrakmatova considers that «to translate phraseological units from one language into another one includes national colour peculiarities, author's use of phraseological units in figurative meaning (author's, personal), problems of correct transferring of the phraseological units used in particular historical time. A translator should know basic etymology of each fixed phrase, speech culture of the people and then choose a proper equivalent. In its turn, this equivalent should be equal in grammatical form, emotional-expressive meaning, internal structure and stylistic use» (Abdyrakhmatova, 2011). According to A.Aldasheva, a translator should find suitable equivalent. For this purpose it is very essential to know to the letter and master «background information», «background knowledge», an idea and main content of an original, language-stylistic skill of an author, lexical-grammatical system of both languages. A translator must distinguish 2 languages, his proper and appropriate translation can raise quality level of translation version (Aldasheva, 2006).

\section{Materials and Experiment Methods}

It follows that a translator's principal duty is complete transferring of full content of an original, as factual resemblance of an original and translation version is very important. Fixed phrases are units which indicate national-cultural coloring of people; this is a reason that it is quite effortful to translate them. To find an applicable substantial closeness between potential equivalence and real parity of an original and translation version is one of the primal tasks of a translator.

Both science and research methods are developing due to the flow of time. To distinguish, to differ phraseological 
units are rather complicated task for a translator. For example, meaning of the multicomponent set expression can be different; some of them can have historical information. During translation process rigorous meaning of phraseological units can be changed or even mispresented, if a translator does not know full-scale nature of an original language.

In order to analyze translation techniques of set expressions from the theoretical side, it is necessary to divide translation methods of all fixed phrases of the given language. Many scholars resort to this linguistic classification as an initiation, which differentiate phraseological units as translatable and not transferable, in accordance with a number of compound parts and their metaphorical distinctions. We are aware of the following phrases: contraction fixed phrases (idioms), combined phraseological locutions (metaphorical units), accordant and phraseological words (In compliance with the classification of Sh.Bally, V.V.Vinogradov, B.A.Laryn, N.M.Shanskiy). In accordance with Ya.I.Rescker, this classification is convenient method in translation theory and practice. However, he considers only contraction fixed phrases and combined phraseological locutions. He contemplates that we should use complete variation method while translating contraction fixed phrases and image alteration way during interpretation of combined phraseological locutions.

S.Vlahov and S.Floryn show the following ways of translation of phraseological units from an original language into translation language:

1) To translate fixed phrases with the help of equivalents in translation language;

2) To translate phraseological units by means of variant (analog) in translation language;

3) To translate set expressions with the use of non-phraseological language means, If there is neither equivalent nor other version of the phraseological units in an original language (Vlakhov S.I. and Florin S.P., 2006).

Throughout studying special literature on translation phraseological units we have met the next types of them. They are phraseological translation and non-phraseological interpretation. Phraseological translation is interpretation of set expressions of one language into another by means of those fixed phrases which exist in the second language, finding meaningful closeness between an original language and translation one, then presenting suitable phraseological equivalent. In other words, to translate set expressions in an original language with phraseological units of a translation language or to interpret phraseological locutions with phraseological units. We can find such appropriateness in both languages. By way of example: To leave Koryk they hurried to ride horses at the crack of dawn. At dawn he himself woke up Baytas, who came to the city to take him with. All day long he did not get off the horse and was skipping ahead than other wayfarers (Auezov, 2007). Translation version: Last light transition was in prospect, and a boy, a pupil at medrese woke up all his fellow travelers with the first rays of the sun. They got on horses and left Koryk at first light, and the rest of the way the boy galloped ahead of all, at a distance of arm bullet (Auezov, 2007). The translation is exact.

Semi phraseological equivalent is existence of several versions of phraseological units translated from original language into translation one, namely if there are few components of the fixed phrase in an original language, then there will be many elements in a translation language and on the contrary, if there are a lot of units in a phraseological locution, in a translation language they can be just a few. This kind of interpretation can often be met.

To take one example: Baylayin bayladin (Байлауын байладың) - You said you did. Now, hey, talabin zher kilmandar (талабын жер қылмаңдар) do not put in shame the intention of my young children in front of strange people. You will not derogate from dignity if you serve the deceased. Forget quarrel and dissension, as soon as you are a man! Tirisinde algys almasan, endi, tym kurisa, oli aruaginan kargys alma (Тірісінде алғыс алмасаң, енді, тым құрыса, өлі аруағынан қарғыс алма) If you did not receive gratitude during their lifetime of, do not get damn from ancestors' spirits. Sons and my daughters-in-law, be attentive to people! Otymen kyr, kulimen shyk konaginnin! (Отымен кір, күлімен шық қонағының!) Be affable and courteous to your guests! True trial comes not in a battle and in a temper, but in an open-heartedness and benevolence! Even you are exhausted do not knit your brows! Kabak shytpa! (қабақ шытnа) Be glad and treat your guests properly! Do not become conceited and get worked up! Treat your guests silently and gently! Otherwise while all relatives are here «tort kozi tugel otyr goy» (төрт көзі түгел отыр ғой) I am telling you, better I will die! One of you are called an idle talker, second is named like an ill-bred person, others are boasters, dare-devil, braggarts, many of you get drunk during such assembly and gathering, show rudeness and tactlessness and then get fame like this! (Auezov, 2007). Translation: - You have made a decision. Now, my children, do not lose your face in front of people, when they come from a distance. One and all help my children, who try to make as many good deeds as possible. Be human-beings; do not lose your dignity, forget your altercation and discord, show your respect for the departed. If you had not done anything kind to him during the lifetime of, do it now, after his death. Do not incur curse of the late's spirit. My children, be attentive and well-mannered to your guests! True man manifests his prowess not in a battle with enemies, but in noble communication with friends. Die from tiredness, but do not frown! Treat your guests with merry faces, smile, cheerfully and deftly. But do not lose your merit. Be well-wishing, do not be boasters and chatterboxes. Show modesty and generosity! If not, I am telling you in front of all relatives, better I will pass away (Auezov, 2007). 
Relative phraseological equivalent is the same in meaning but differ in syntactical structure, synonymous components, and morphological compound. Relative phraseological equivalent is not frequently met in translation. For instance: - Shukiman, erulige karuli bar (еруліге қарулы бар) There is always someone better for that who thinks he is the best. Both I and Erbol do not forget song «Topaykok» sang in that house. Translation: - Nonetheless, one good turn deserves another. Now you should sing. Both I and Erbol request you to sing «Topaykok» like you did it in that house.

Phraseological analog (adequacy) is a fixed phrase which is quite adequate to the phraseological unit in original language, but this phraseological locution keeps its own characteristics. For instance, Kadalyp kaldy (Қадалып қалды) he stared at him, aktarila tusty (ақтарыла түсті) - to tumble out, to have a heart-to-heart talk; zhurekti, kayratty (жүректі, қайратты) - courageous, brave.

Non-phraseological translation is a type of interpretation done by non-phraseological means. In such cases these translation methods are used like lexical equivalent, loan translation, description, combined translation. These types of interpretation are used when no phraseological equivalent is found. Shortcomings of this kind of translation are that phraseological figurativeness, expressivity, informative colouring can be lost. Besides, antonymous translation and word for word translation can be also applied.

\section{Results and Discussion}

Consequently, we have considered several methods of phraseological units' translation from one language into second one. According to translation order they can be divided in the following way. The first one is a fixed phrase which can be met in both languages. There is no need to translate them; it is enough to find suitable and proper phraseological locution from mother tongue's treasure. Sometimes they can match both in meaning and form. The second one is set expression that does not have ready samples in Kazakh language. We have to use free translation to interpret them, but keep their content and shape. But all peculiarities of proverbs and sayings should be kept. In other words, proportionality, consonance, richness of content, impression should be fully given; they all must impact on a reader. The third is translation of phraseological units with the help of word for word interpretation. The forth is to turn set expressions by means of equivalents (adequate). The fifth is to use free translation to interpret fixed phrases.

Undoubtedly, problem of interpretation of phraseological units from one language to another is very significant and complicated task. We do think that it is possible and necessary to translate phraseological units. Usage rate of fixed phrases in creativity of each writer also shows to use translation ways as much as possible. We can name the next types of translation methods of phraseological units in epopee of M.Auezov «The way of Abai». The first: a translator tried to transfer completely content and form, expressive-emotional impression; the second: even the meaning of idioms is presented correctly, but there are some changes in lexical-grammatical structure of phraseological units. It implies that substantial- figurative meaning is kept not fully but half. The third: we can use fixed phrases as ready equivalents appeared as a result of life and situational similarity of two nations. There are plenty of such lexical-semantic groups in each nation. Just we will have to find them. There are also phrases which cannot abide by these rules. These idioms have national distinct colouring. If they are translated they can lose their national singularity, on the other hand we cannot leave them without translation. Judging by these features they can be added to idioms. A. Kim also considered different methods of them. By and large, he tried to convey various difficult set expressions of Kazakh language by means of Russian language materials. .

Whilst analyzing features peculiar to M.Auezov's work, we have noticed that there are plentiful lingual devices that distinguish clearly his proper singularity and also that Russian language has sufficient opportunity to translate them into Russian. It is vital to determine stylistic functions of phraseological units in the text. This translation played significant role in increasing of Russian Language Culture.

But not all translation is in exemplary level. Even there are enough disadvantages in transferring of the specific problem which we are studying currently. That is the reason that we should reconsider the translation and do it again appropriate to the present time.

To translate phraseological units in «The Way of Abai» it is essential to define their ranges, types, purposes. Because in accordance with main aim of a writer, fixed phrases fulfill stylistic functions. In that case we should examine the translation in concordance with stylistic intentions of a writer.

\section{Conclusions}

M.Auezov used phraseological units to identify clearly his characters' images. We can mention the following types of that usage. M.Auezov sometimes used simple aphorisms of people without any changing, but according to the personages' 
actions, characters the author occasionally apply fixed phrases, vary and brighten them. He introduced a change into lexical-grammatical structure of the phraseological units. All in a breath, author's heroes speak in specific way, with absolutely new aphorisms. It is not easy to distinguish fixed phrases' form, kind, and emotional- esthetic effect. Judging by the translation, sometimes it is impossible to convey these peculiarities with the help of Russian language. According to A. Pushkin, a translator should transfer a writer's ideas, views. As for Gogol's opinion about translation, he believes that in order to become closer to an original text, sometimes a translator should move aside from original text's words. L.Tolstoy assumes that it is not enough to translate words and meaning, it is significant to convey an impression of the text. K.I.Chukovskiy appealed to interpret laughter into laughter, smile into smile. Nevertheless, all the opinions above do not contradict general rules of a translation. There are text parts in each work that cannot be translated conventionally. I call it conventionally as sometimes it is quite impossible to translate some parts. These untranslatable parts are called like phraseological units.

\section{References}

Avakova, R.A., (2009). Theory of Phraseology. Almaty, 292 (3)

Aytbayev, O., (1975). Phraseological phenomenon in translation. Almaty, 228 (180)

Aldasheva, A., (2006). Translation Studies: linguistic and lingvocultural problems. Almaty, 248 (162-168)

Abdyrakhmatova, N.K., (2011). Pecularities of interlingual transposition of phraseologiacl units (research of lingual-cultural specifics of the translation of novel «The Day Lasts More Than a Hundred Years» by Ch.Aytmatov into German and Kyrgyz languages). Bishkek, 23 (11)

Vlakhov S.I. \& Florin S.P., (2006). Untranslatable in translation. Moscow, 343 (232)

Auezov M., (2007). The Way of Abai. First book. Almaty, 368 (3, 234)

Auezov M., (2007). The Way of Abai. First book (Translation of A.Kim). Almaty, $470(3,228)$

Card index of idiomatic set expressions' translation into Russian language in "Abai» novel (I,II volumes) /Archives of M.Auezov's literary-memorial museum-house. LMMA. Kpr-1, file №36.

Kozhakhmetova, Zh., Zhaysakova, R., Kozhakhmetova, Sh., (1988). Kazakh-Russian phraesological dictionary. Almaty, 224

Kaliyeva, S.E., (2007). Usage peculiarities of phraseological units in fiction prose. Almaty. 129 ()

Translation Studies and significant problems of literary comparative linguistics. (2009). The materials of International scientific-theoretical conference, Almaty. 